\title{
Activin A reduces luteinisation of human luteinised granulosa cells and has opposing effects to human chorionic gonadotropin in vitro
}

\author{
Michelle Myers, Sander van den Driesche, Alan S McNeilly ${ }^{1}$ and W Colin Duncan \\ Obstetrics and Gynaecology, Department of Reproductive and Developmental Sciences, University of Edinburgh, 47 Little France Crescent, Edinburgh \\ EH16 4TJ, UK \\ ${ }^{1}$ MRC Human Reproductive Sciences Unit, Queen's Institute of Medical Research, Centre for Reproductive Biology, 47 Little France Crescent, Edinburgh \\ EH16 4TJ, UK \\ (Correspondence should be addressed to W C Duncan at Obstetrics and Gynaecology, Simpson Centre for Reproductive Health, Royal Infirmary of Edinburgh, \\ 51 Little France Crescent, Edinburgh EH16 4SA, UK; Email: w.c.duncan@ed.ac.uk)
}

\begin{abstract}
The transition of the dominant follicle into the corpus luteum is of fundamental reproductive importance. Luteinisation involves disparate changes in the gene expression of follicular granulosa cells that differentiate into the granulosa-lutein cells of the corpus luteum after the gonadotrophin surge. We have shown that activin and human chorionic gonadotropin (hCG) have opposing effects during luteolysis. Therefore, we hypothesised that activin A was an inhibitor of luteinisation that was blocked during the pre-ovulatory gonadotrophin surge. Ovarian tissue and cells were collected from women with regular cycles having hysterectomy and women undergoing oocyte retrieval for assisted conception. Genes that changes during luteinisation were investigated in primary cultures of luteinised granulosa cells exposed to activin A and hCG in vitro. hCG promotes a luteinised granulosa cell phenotype, while activin A promotes a more
\end{abstract}

follicular phenotype in luteinised cells by upregulating granulosa cells markers such as FSHR, HSD11B2 and downregulating LHCGR. In addition, activin A blocked hCG upregulation of STAR, HSD3B1 and HSD11B1 and downregulation of oestrogen receptor $\alpha$. Activin A antagonised hCG effects in a dose-dependent manner and could block the hCG-stimulated molecular inhibitors of activin action (inhibin $\boldsymbol{\alpha}$-subunit, follistatin and TGFBR3). These studies show that hCG and activin A have opposing effects on luteinised granulosa cells and some effects of activin are seen only in the presence of hCG. While hCG can inhibit activin action in granulosa cells to facilitate luteinisation, activin A can promote an unluteinised phenotype in luteinised granulosa cells. This confirms the importance of adequate activin withdrawal during luteinisation in women.

Journal of Endocrinology (2008) 199, 201-212

\section{Introduction}

The transition of a dominant follicle into the corpus luteum is one of the fundamental processes in reproductive biology. It involves the transformation of follicular cells into the most active steroidogenic endocrine gland in the body. Luteinisation, the process whereby follicular granulosa cells differentiate into the granulosa-lutein cells of the corpus luteum involves marked and disparate morphological, biochemical and cellular changes. The granulosa cells become terminally differentiated, such that they do not divide again and develop the enzyme machinery necessary for massive progesterone synthesis. This highly organised process, that is tightly orchestrated by steroid hormones, gonadotrophins and growth factors, is associated with structural and functional changes that characterise the folliculo-luteal transition. In a conception cycle, a viable corpus luteum is essential to the success of early gestation, while, in a nonconception cycle, its demise is necessary for the next wave of folliculogenesis.
The molecular pathways involved in the luteinisation of granulosa cells are not entirely clear. While the luteinising hormone (LH) surge or addition of LH or human chorionic gonadotrophin (hCG) initiate luteinisation, experimental work clearly shows that the removal of granulosa cells from the follicle causes spontaneous luteinisation in the absence of LH. Indeed, this hampers the study of follicular granulosa cells in vitro. It is therefore believed that luteinisation is a differentiation pathway that is programmed before antral formation, and the only way the follicles can escape this fate is by inhibitory factors (Wehrenberg \& Rune 2000). Literature suggests that the follicle itself can provide a milieu in order to discourage luteinisation (Channing et al. 1980, Eppig et al. 1997, Murphy 2000), and inhibitor(s) of such magnitude may actually be present in follicular fluid (Ledwitz-Rigby et al. 1977, Channing et al. 1978) or come directly from the oocyte itself (Vanderhyden \& Macdonald 1998, Brankin et al. 2003). It therefore appears that the LH surge is able to remove such inhibitory factors, disrupt connections between granulosa cells and the oocyte and/or induce genes that facilitate luteinisation. 
One molecule that may have a role in the prevention of luteinisation is activin A. Activin A, a dimeric glycoprotein and member of the transforming growth factor (TGF) $-\beta$ superfamily is found in the follicular fluid and can delay granulosa cell luteinisation and/or atresia by decreasing basal and hCG-induced progesterone in human (Rabinovici et al. 1990, Di Simone et al. 1994), monkey (Brannian et al. 1992), sheep (Shidaifat et al. 2001) and goat (Shidaifat 2001) granulosa cells. In addition, we have shown that activin A action may be involved in promoting luteolysis, at the end stage of the luteal phase (Myers et al. 2007a). We believe that during maternal recognition of pregnancy one of the roles of hCG may be to inhibit activin action. We therefore hypothesised that activin A was anti-luteal and, at the start of the luteal phase, one of the roles of the LH surge is to remove activin $A$ and facilitate luteinisation. At the end of the luteal phase, activin A action increases to facilitate luteolysis and in early pregnancy hCG, acting through the LH receptor, continues to inhibit activin A action and facilitate luteal maintenance.

In this current study, we tested the hypotheses that a) activin A and hCG have opposing effects in luteinised granulosa cells and b) luteinisation of granulosa cells involves a differentiation step that is not terminal and that activin A can return the luteinised granulosa cell to a more follicular phenotype.

\section{Materials and Methods}

\section{Collection of human ovarian tissue}

Whole ovaries were used to highlight differences between the granulosa cells of the follicle and the granulosa-lutein cells of the corpus luteum. Normal ovarian tissue was collected $(n=3)$ from women (average age 45) with regular cycles undergoing hysterectomy for benign conditions, leiomyomata or adenomyosis, with morphologically normal ovaries. Two ovaries were from the mid-luteal phase and one was from the early follicular phase. Tissue collection was approved by the local medical research ethics committee and all women gave informed consent.

\section{Isolation of human luteinised granulosa cells}

The medical ethics committee separately approved the collection of cells from patients undergoing assisted conception. With patient consent, follicular fluid was collected from women undergoing transvaginal oocyte retrieval for in vitro fertilisation after ovarian stimulation using a standard procedure (Duncan et al. 2005a). Isolation of luteinised granulosa cells using Percoll density gradient centrifugation was carried out as described previously (Duncan et al. 2005b, Myers et al. 2007a).
Activin A and hCG treatments in primary cultures of luteinised granulosa cells

Pooled luteinised granulosa cells (100 000 per well of 3-5 patients) were cultured in 24-well plates precoated with matrigel (BD Biosciences, Bedford, MA, USA) in serum-free culture medium (supplemented DMEM/F12 Ham mixture) from collection (Day 0), as described previously (Duncan et al. 2005b). Briefly, cells were refreshed with serum-free culture medium every 2 days after until day 5 , when they were treated with the combinations of human recombinant activin A (Myers et al. 2007a; R\&D Systems Inc., Abingdon, UK) and/or a maximally stimulating dose of hCG (Serono Laboratories). The following six treatments were added to luteinised granulosa cells: 1) $0 \cdot 1 \%(\mathrm{w} / \mathrm{v}) \mathrm{BSA}$ in sterile PBS; 0.1\% (w/v) BSA with 2) $100 \mathrm{ng} / \mathrm{ml} \mathrm{hCG;3)} 25 \mathrm{ng} / \mathrm{ml}$ activin A; 4) $100 \mathrm{ng} / \mathrm{ml}$ activin A; 5) $25 \mathrm{ng} / \mathrm{ml}$ activin A with $100 \mathrm{ng} / \mathrm{ml} \mathrm{hCG}$; and 6) $100 \mathrm{ng} / \mathrm{ml}$ activin A with $100 \mathrm{ng} / \mathrm{ml}$ hCG. Each pooled experiment for the following treatments was carried out at least thrice to avoid biological bias.

\section{Preparation of cDNA from luteinised granulosa cells cultures}

Luteinised granulosa cell mRNA was extracted using RNeasy mini-spin columns after lysis by the addition of RNeasy lysis buffer (Qiagen). Lysates were frozen until processed as per the manufacturers' protocols, then DNase treated with on-column DNaseI (Qiagen) and quantified using the NanoDrop ND-1000 Spectrophometer (NanoDrop Technologies, Wilmington, DE, USA). Messenger RNA was then reverse transcribed into cDNA using random hexamers (Applied Biosystems, Foster City, CA, USA).

\section{Quantitative analysis of gene expression by RT-PCR}

Quantitative real-time PCR (QRT-PCR) was carried out on the ABI PRISM 7900 heat-cycler sequence detection system (Applied Biosystems) using specific primers and probes (Eurogentec Ltd., Southampton, UK) for each gene of interest (Table 1), and levels were related to a ribosomal $18 \mathrm{~S}$ internal control (Applied Biosystems). All samples were performed in duplicate and a relative comparison was made to an appropriate tissue control tissue cDNA.

\section{Analysis of progesterone secretion by luteinised granulosa cells}

Progesterone concentrations were measured from collected culture medium using a plate modification of a standard progesterone RIA. Pooled luteinised granulosa cells $(n=6)$ were cultured for 5 days as described previously, then maximal doses of recombinant $\mathrm{LH}(100 \mathrm{ng} / \mathrm{ml})$ or follicle stimulating hormone (FSH; $100 \mathrm{ng} / \mathrm{ml}$; Serono Laboratories) were added with low-density lipoprotein $(50 \mathrm{mg} / \mathrm{l})$ in the presence or absence of activin $(100 \mathrm{ng} / \mathrm{ml})$. The intra-assay co-efficient of variation was $<4 \%$ and the inter-assay co-efficient of variation was $<11 \%$. The detection limit of the progesterone assay was $0 \cdot 1 \mathrm{nmol} / 1$. 
Table 1 List of all human primer/probe sequences used for Taqman quantitative RT-PCR

\begin{tabular}{|c|c|c|c|}
\hline & Fwd primer $5^{\prime}-3^{\prime}$ & Rev primer $5^{\prime}-3^{\prime}$ & Probe $5^{\prime}$-FAM-TAMRA-3' \\
\hline \multicolumn{4}{|l|}{ Gene } \\
\hline HSD11B1 & AAGATGTTCCTGCATGGATTTC & AGCTCTGCGCCAAGAAGAAGT & $\begin{array}{l}\text { TGACAGCTCACTCTGGACCACTCTTCTGA } \\
\text { Rae et al. (2004) }\end{array}$ \\
\hline HSD11B2 & GGCCAAGGTTTCCCAGTGA & GTTGTGCCAGGAGGGTGTTT & $\begin{array}{l}\text { CTCTGCGCCTCTCCACTGTTTCATGA } \\
\text { Rae et al. (2004) }\end{array}$ \\
\hline ESR1 & TGATTGGTCTCGTCTGGCG & САТGСССТСТАСАСАТТTТССС & $\begin{array}{l}\text { TGCTCCTAACTTGCTCTTGGACAGGAACC } \\
\text { Henderson et al. (2003) }\end{array}$ \\
\hline INHA & CTCGGATGGAGGTTA CTCTTTCAA & GAAGACСССССАСССТTAGA & $\begin{array}{l}\text { TATGAGACAGTGCCCAACCTTCTCACGC } \\
\text { Casagrandi et al. (2003) }\end{array}$ \\
\hline TGFBR3 & AGCAGGTGAGGAACCCCAG & AGTGTTGTATAGCTCCATGTTGAAGG & $\begin{array}{l}\text { CCAGGAACAGCCCCACGGAAACA } \\
\text { Casagrandi et al. (2003) }\end{array}$ \\
\hline FST & CAGTAAGTCGGATGAGCCTGTCT & САGСTTCСТTCATGGCACACT & $\begin{array}{l}\text { TGCCAGTGACAATGCCACTTATGCCA } \\
\text { Casagrandi et al. (2003) }\end{array}$ \\
\hline INHBA & GGACATCGGCTGGAATGACT & GGCACTCACССТCGCAGTAG & $\begin{array}{l}\text { ATCATTGCTCCCTCTGGCTATCATGCC } \\
\text { Casagrandi et al. (2003) }\end{array}$ \\
\hline FSHR & AACACCCATCCAAGGAATGG & GGGCTAAATGACTTAGAGGGACAA & $\begin{array}{l}\text { TCTTCAGCTCCCAGAGTCACCAGTGGTTC } \\
\text { Salas et al. (2006) }\end{array}$ \\
\hline LHCGR & CTGAAATACTGATCCAGAACACCAA & GCTCAAGTATTTTAATCCGGGAAGA & $\begin{array}{l}\text { ATCTGAGATACATTGAGCCCGGAGCAT } \\
\text { Ji et al. (2002) }\end{array}$ \\
\hline$S T A R$ & TTGCTTTATGGGCTCAAGAATG & GGAGACССTCTGAGATTCTGCTT & $\begin{array}{l}\text { CATGCGCTGGCAGTACATGTGCAC } \\
\text { Oskarsson et al. (2006) }\end{array}$ \\
\hline HSD3B1 & Assay on demand (Applied Biosystems Hs00605123_m1) & & \\
\hline
\end{tabular}




\section{Immunohistochemistry}

Immunolocalisation of oestrogen receptor $\alpha$ (ESR 1$)$ was carried out using a mouse monoclonal antibody (Vector Laboratories, Peterborough, UK) in $5 \mu \mathrm{m}$ paraffin tissue sections of human ovary prepared on poly-L-lysine-coated microscope slides. These sections were dewaxed, rehydrated, washed in PBS, subjected to antigen retrieval in $0 \cdot 01 \mathrm{M}$ citric acid ( $\mathrm{pH} \mathrm{6.0)} \mathrm{for} 5 \mathrm{~min}$ and left to cool to room temperature. All sections were washed and placed in $3 \%(\mathrm{v} / \mathrm{v}) \mathrm{H}_{2} \mathrm{O}_{2} /$ methanol for $30 \mathrm{~min}$, followed by an avidin and biotin block and a further block using normal goat serum (NGS, Diagnostics Scotland, Edinburgh, UK) diluted 1:4 in PBS containing 5\% (w/v) BSA (NGS/PBS/BSA) for $1 \mathrm{~h}$ at room temperature. Sections were incubated overnight in primary antibody diluted 1 in 20 in NGS blocking solution at $4{ }^{\circ} \mathrm{C}$.

All sections were then washed twice for $5 \mathrm{~min}$ in PBS before incubation with biotinylated goat anti-mouse secondary antibody (DAKO Corp., Cambridge, UK) 1 in 500 in PBS. Incubations lasted for $1 \mathrm{~h}$ and were followed by two washes for $5 \mathrm{~min}$. Thereafter, sections were incubated in avidin-biotin complex-horse radish peroxidase (DAKO) for $1 \mathrm{~h}$ as per the manufacturers' instructions. Incubations were at room temperature for $1 \mathrm{~h}$ and all sections were washed in PBS $(2 \times 5 \mathrm{~min})$ and bound antibodies visualised by incubation with liquid 3,3'-diaminobenzidine tetrahydrochloride (DAKO). Sections were counterstained lightly with haematoxylin to enable cell identification. Negative controls for each antibody examined were performed identically to the above protocol with primary antibody incubations substituted with blocking serum containing non-specific immunoglobulins at the same concentration. Images were captured using an Olympus Corp., Provis microscope (Olympus Corp., Optical Co., London, UK) equipped with a Kodak DCS330 camera (Eastman Kodak Co.), stored on a HP computer and assembled using Photoshop 7.0.1 (Adobe Systems Inc.)

\section{Fluorescent immunohistochemistry}

Co-localisation experiments of $11 \beta$-hydroxysteroid dehydrogenase type 1 (HSD11B1; Cayman/IDS Ltd, Bolton, UK) and type 2 (HSD11B2; kind gift from Prof. Ian Mason, The University of Edinburgh, UK) were washed, subjected to antigen retrieval and blocked (initially with NGS/PBS/BSA), as described previously. Negative controls were treated exactly the same as positive slides with both primary antibody steps omitted. Rabbit anti-HSD11B1, diluted 1 in 100 in NGS/PBS/BSA, was incubated on sections overnight at $4{ }^{\circ} \mathrm{C}$. Sections were then washed and slides were incubated with goat anti-rabbit IgG 488 (DAKO) diluted 1 in 200 in PBS for $1 \mathrm{~h}$.

For co-localisation with anti-HSD11B2, sections were re-blocked with normal donkey serum (NDS)/PBS/BSA for $1 \mathrm{~h}$ and then incubated with sheep anti-HSD11B2 diluted 1 in 50 in donkey serum. Sections were washed and incubated with donkey anti-sheep peroxidase (DAKO) 1 in 200 in
NDS/PBS/BSA for $30 \mathrm{~min}$ before washing and incubating for 10 min with tyramide Cy3 (TSA plus cyanine 3 system; Perkin-Elmer Life Sciences, Boston, MA, USA) diluted 1 in 50 in the supplied buffer to amplify the HSD11B2 immunostaining with red fluorescence.

Nucleic acids were labelled with To-Pro 3 and washed and mounted in Permafluor (Beckman Coulter, High Wycombe, UK). Fluorescent images were captured using an LSM 510 Axiovert $100 \mathrm{M}$ confocal microscope (Carl Zeiss Ltd, Welwyn Garden City, UK). Images of HSD11B1 and HSD11B2 were analysed comparatively by standardising the computer settings for each isoform. Therefore, the relative intensity of staining for each isoform corresponds to abundance of protein levels. All images were compiled using Photoshop 7.0.1 (Adobe Systems Inc).

\section{Statistical analysis}

Statistical analyses used are highlighted in the figure legends. Parametric statistics were used if the data were normally distributed with similar standard deviations. Groups were analysed by ANOVA with Bonferroni pairwise comparisons used; if the data were not normally distributed, nonparametric statistics were used. Groups were analysed by Kruskal-Wallis test with Dunn's multiple comparison test. Differences were considered significant at $P<0 \cdot 05$ level.

\section{Results}

The effects of activin and hCG on luteinised granulosa cell steroidogenic pathway

Luteinised granulosa cells express the enzymatic machinery to synthesise progesterone. Maximally stimulating doses of hCG $(100 \mathrm{ng} / \mathrm{ml})$ maintained the high $\mathrm{LH}$ receptor $($ LHCGR) and low FSH receptor $(F S H R)$ expression and increased the expression of steroidogenic acute regulatory protein (STAR; $P<0 \cdot 001)$ and $3 \beta$-hydroxysteroid dehydrogenase (HSD3B1; $P<0 \cdot 001)$. In contrast, physiological concentrations of activin A $(25 \mathrm{ng} / \mathrm{ml})$ inhibited LHCGR expression $(P<0 \cdot 01)$ and induced FSHR $(P<0 \cdot 05$; Fig. 1). Activin A reduced LH-stimulated progesterone secretion $(P<0 \cdot 05)$. This effect was not solely due to downregulation of $\mathrm{LH}$ receptors as activin A also reduced FSH-stimulated progesterone secretion $(P<0 \cdot 05$; Fig. 2$)$.

The effects of activin and hCG on other molecules that change during luteinisation

The HSD11B enzyme isoforms change during luteinisation (Michael et al. 1997, Tetsuka et al. 1997, Yong et al. 2000, Thurston et al. 2003). The predominant isoform in follicular granulosa cells is HSD11B2 (Fig. 3A-C), while the predominant isoform in granulosa-lutein cells of the corpus luteum is HSD11B1 (Fig. 3D-F). This suggests that during 

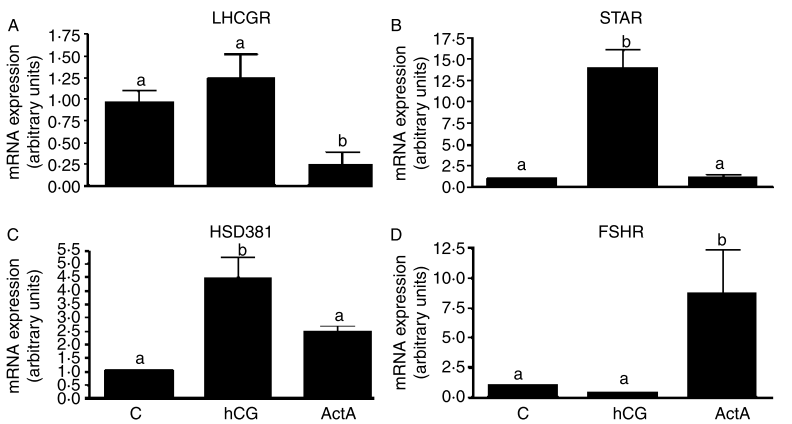

Figure 1 Differential effects of activin A (ActA) and hCG on key genes involved in the steroidogenic pathway compared with unstimulated control (C) cells. (A) HCG maintained the expression of $\mathrm{LH}$ receptor (LHCGR; $P>0 \cdot 05$, Kruskal-Wallis); however, activin A inhibited receptor expression in primary cultures of luteinised granulosa cells $(P<0 \cdot 01$, Kruskal-Wallis). (B and $\mathrm{C})$ Key regulators of the steroidogenic pathway, STAR $(P<0 \cdot 001$, Kruskal-Wallis) and $3 \beta \mathrm{HSD}$ (HSD3B1; $P<0 \cdot 001$, ANOVA) were upregulated by hCG treatment, while activin A had no effect upon these genes $(P>0 \cdot 05)$. (D) hCG maintained the low expression of follicle stimulating hormone receptor (FSHR) in vitro; however, treatment with activin A significantly upregulated receptor expression $(P<0 \cdot 05$, ANOVA).

luteinisation HSD11B1 is upregulated while HSD11B2 is downregulated. In addition, immunolocalisation of ESR1 is different in the follicle and in the corpus luteum (Saunders et al. 2000, van den Driesche et al. 2008). Granulosa cells of the antral follicle clearly express ESR1 while expression in the granulosa-lutein cells of the corpus luteum appears negligible (Fig. 3G and H). This suggests that the ESR1 expression is downregulated during luteinisation.

As expected (Myers et al. 2007b), hCG markedly upregulated the expression, of HSD11B1 $(P<0 \cdot 001)$, in cultures of luteinised granulosa cells by over 30-fold (Fig. 4A). Although activin A (at either 25 or $100 \mathrm{ng} / \mathrm{ml}$ ) alone had no effect upon HSD11B1 expression, it was evident that when added simultaneously with hCG activin opposed the effect of hCG $(P<0 \cdot 01$; Fig. 4A). The opposite effect tended to be seen when HSD11B2 isoform was examined. HCG tended to reduce, while activin A tended to increase HSD11B2 expression (Fig. 4B). The action of activin $\mathrm{A}$ on the expression of HSD11B2 was inhibited by hCG (Fig. 4B). A similar pattern was seen when expression of ESR1 was investigated (Fig. 4C). In cultures of luteinised granulosa cells, hCG decreased receptor expression $(P<0 \cdot 05$; Fig. 4C). Activin A (25 or $100 \mathrm{ng} / \mathrm{ml}$ ) maintained ESR 1 expression although in simultaneous treatments with hCG, hCG tended to attenuate this response (Fig. 4C).

\section{Activin A inhibits hCG effects in a dose-dependent manner}

To further elucidate the disparate effects of activin $\mathrm{A}$ and hCG, we added the activin A at two different concentrations $(25$ and $100 \mathrm{ng} / \mathrm{ml})$ simultaneously with hCG $(100 \mathrm{ng} / \mathrm{ml})$ to cultures of luteinised granulosa cells (Fig. 5). Herein, we show that activin A and hCG have opposing effects on the expression of candidate genes in a dose-dependent fashion. Increasing concentrations of activin A decreased the expression of LHCGR (Fig. 5; $P<0 \cdot 01$ ) in a dose-dependent manner in the presence of hCG, and similar patterns were also observed for STAR $(P<0 \cdot 001)$ and HSD11B1 $(P<0 \cdot 01$; Fig. 5). In contrast, the FSHR expression tended to increase with the dose of activin A (Fig. 5).

\section{The likely effects of activin $A$ and $h C G$ on activin $A$ action}

Activin action can be inhibited at several levels including synthesis, secretory protein and reception. Increasing the expression of the inhibin $\alpha$-subunit (INHA) will increase inhibin A and reduce activin A synthesis. Follistatin (FST) will bind to activin $A$ and inhibit its action and the expression of $\beta$-glycan (TGFBR3) facilitates inhibin A inhibition of activin action at a receptor level. The addition of hCG increased the expression of the INHA subunit $(P<0 \cdot 01)$, and its TGFBR3 receptor $(P<0 \cdot 001$; Fig. 6). Activin A lowered the hCGstimulated expression of FST $(P<0.01)$ and tended to increase the expression of the activin $\beta$ A (INHBA) subunit (Fig. 6). These data suggest that hCG may be able to withdraw activin A action at multiple levels.

\section{Discussion}

We have investigated the effects of activin A and hCG on human luteinised granulosa cells in vitro. Previously, we have suggested that hCG and activin have opposing effects on the regulation of tissue remodelling associated with luteolysis (Myers et al. 2007a). Herein, we suggest that hCG and activin A have opposite effects on the luteinised granulosa cells involved in luteal formation. Activin A appears to reduce the luteinisation of luteinised granulosa cells so they have a more follicular phenotype, while hCG increases the luteinisation to a more luteal phenotype. Although effects of activin on granulosa cells has been previously studied (Hutchinson et al.

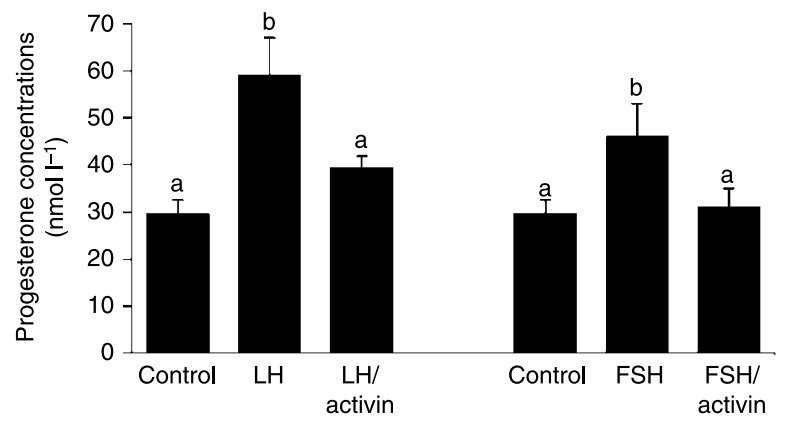

Figure 2 Gonadotrophin $(100 \mathrm{ng} / \mathrm{ml})$-induced progesterone secretion was significantly inhibited by activin $A(100 \mathrm{ng} / \mathrm{ml})$ using both $\mathrm{LH}(P<0 \cdot 05$, ANOVA) and FSH $(P<0 \cdot 05$, ANOVA $)$ in the culture medium of primary cultures of luteinised granulosa cells. 

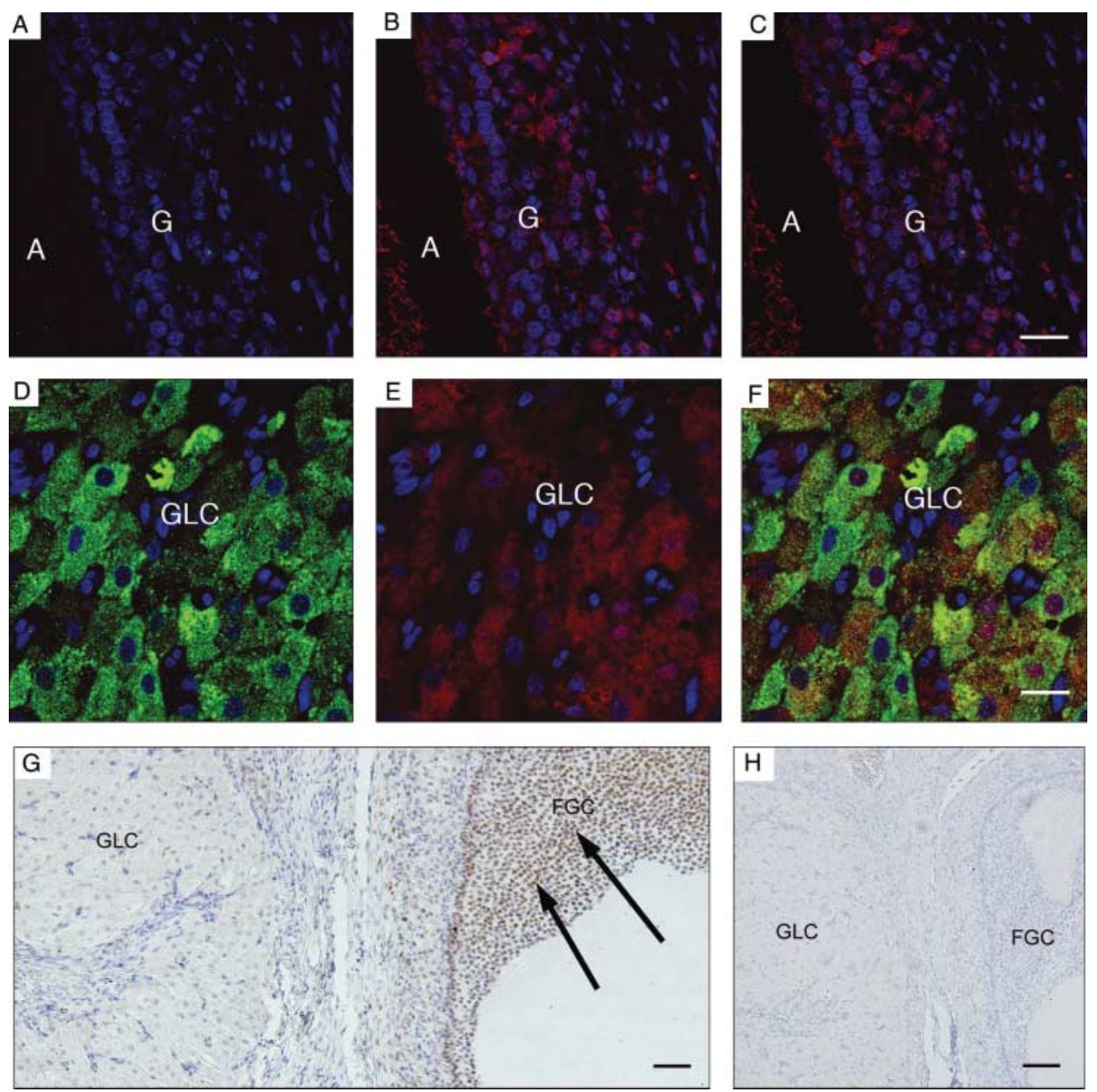

Figure 3 Immunolocalisation of HSD11B1, HSD11B2 and ESR1 in the human ovary. Double immunofluorescence of HSD11B1 in green (A and D) and HSD11B2 in red (B and $E)$ in the mural granulosa cells $(G)$ of an antral (A) follicle (A-C) and the granulosa-lutein cells (GLC) of the corpus luteum (D-F). Single immunofluorescence clearly demonstrates that HSD11B1 is not expressed in the granulosa cells (A), while HSD11B2 is indeed localised to these cells (B). The granulosa-lutein cells of the corpus luteum express both HSD11B1 in green (D) and HSD11B2 in red (E), with the merge panel $(F)$ showing a predominance of HSD11B1 isoform over HSD11B2. (G) Light field of an ovarian section showing both a corpus luteum and an antral follicle demonstrates that ESR1 is localised to the granulosa cells of the follicle (FGC); however, the staining in the granulosa-lutein cells (GLC) of the corpus luteum is negligible. A negative control for ESR1 shows no staining in either cell type (H). Scale bar $=40 \mu \mathrm{m}(\mathrm{A}-\mathrm{F})$ and $200 \mu \mathrm{m}$ $(\mathrm{G}$ and $\mathrm{H})$.

1987, Shukovski et al. 1991, 1993), this investigation serves to highlight four novel concepts that 1) hCG and activin A tend to have opposing actions on luteinised granulosa cells, 2) activin $A$ can reverse features of luteinisation once it has occurred, 3) some of the effects of activin A are seen only in the presence of hCG and 4) activin may have roles in the regulation of its continued synthesis and action. These studies aim to increase our understanding of the role of activin in the follicular-luteal transition.

Luteinisation of follicular granulosa cells into the granulosa-lutein cells of the corpus luteum is a key element of the follicular-luteal transition. The formation of the corpus luteum itself involves a co-ordinated interplay of fundamental processes such as cell proliferation, cell differentiation, tissue remodelling and angiogenesis that is unparalleled in any other tissue in the adult mammal (Murphy 2000, Fraser \& Duncan 2005, Stocco et al. 2007). The mechanism and regulation of this process is not fully understood but it is driven by a complex co-ordination of steroid hormones, gonadotrophins, cytokines, growth factors and disparate paracrine signalling molecules. There are marked changes to steroidogenic cell functions during luteinisation. Granulosa cells become terminally differentiated, cell division ceases, the cells undergo marked hypertrophy and there are marked changes in the expression of different molecules including steroidogenic enzymes and hormone receptors (Murphy 2000, 

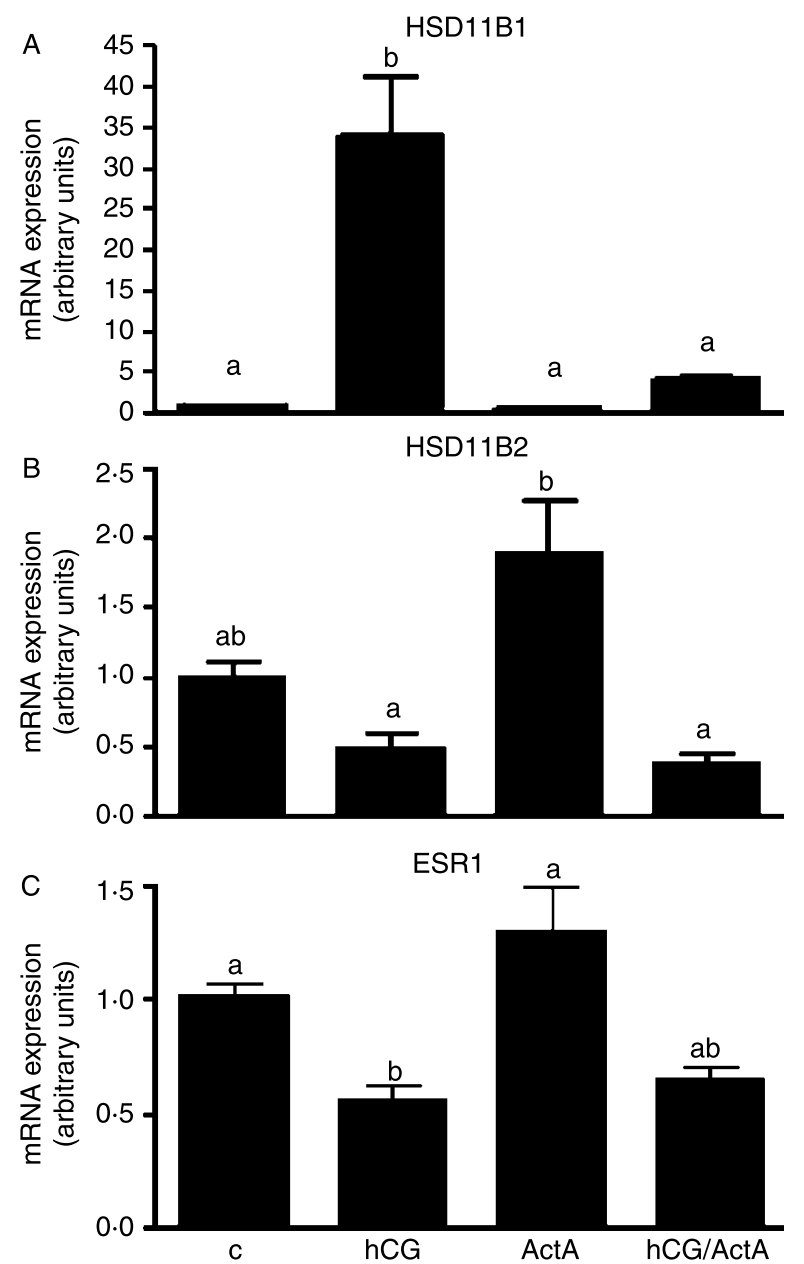

Figure 4 Expression of genes that change during luteinisation. (A) HCG (hCG) upregulated HSD11B1 by over 30 -fold $(P<0 \cdot 001$, ANOVA) compared with control (C) in primary cultures of luteinised granulosa cells, whilst activin $\mathrm{A}$ (ActA) alone had no effect $(P>0 \cdot 05$, ANOVA). However, when added simultaneously with hCG, activin A (hCG/ActA) attenuated the hCG response $(P<0 \cdot 01$, ANOVA). (B) In contrast, HSD11B2 tended to be upregulated by activin A treatment, while hCG significantly attenuated this effect $(P<0 \cdot 05$, Kruskal-Wallis). (C) Expression of ESR1 was decreased by hCG in vitro $(P<0 \cdot 05$, Kruskal-Wallis), while activin A maintained receptor expression. HCG added simultaneously with activin A reduced expression levels of ESR1 similar to those of hCG.

Stocco et al. 2007). The proximal event that initiates ovulation and luteinisation is the pre-ovulatory LH gonadotrophin surge (Filicori 1999, Murphy 2000), mimicked by hCG, acting via $\mathrm{LH} / \mathrm{hCG}$ receptors. $\mathrm{LH} / \mathrm{hCG}$ may directly induce the disparate and marked changes within the follicular granulosa cells phenotype that are necessary for appropriate luteal cell function, while simultaneously withdrawing factors that are thought to inhibit luteinisation.

Inhibitors of luteinisation have been reported in many studies and indeed candidate molecules have been suggested. Indeed, it is clear that luteinisation can occur in the absence of
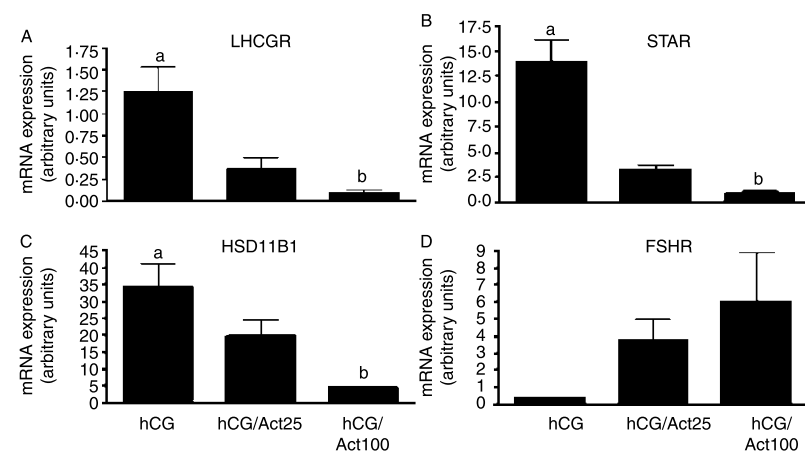

Figure 5 Activin acts in a dose-dependent manner to attenuate the response of hCG. (A) Activin A (Act) attenuated the hCG effect on LHCGR $(P<0 \cdot 01$, Kruskal-Wallis), (B) STAR $(P<0 \cdot 001$, KruskalWallis) and (C) HSD11B1 $(P<0 \cdot 01$, ANOVA) by minimising hCG action in a dose dependent ( 25 and $100 \mathrm{nmol} / \mathrm{l}$ ) manner in primary cultures of luteinised granulosa cells. (D) The opposite trend was observed with the FSHR whereby expression tended to increase with the dose of activin A.

$\mathrm{LH} / \mathrm{hCG}$ when granulosa cells are removed from the follicular environment. The physical presence of the oocyte has been reported to inhibit luteinisation in many species; for example, the mouse (Vanderhyden et al. 1993), pig (Coskun et al. 1995) and human (Seifer et al. 1996) with candidate factor(s) acting in a paracrine signalling fashion from the oocyte to the granulosa cells. Furthermore, factors in the follicular fluid of small, but not large follicles, have also proved to be inhibitory (Ledwitz-Rigby et al. 1977, Channing
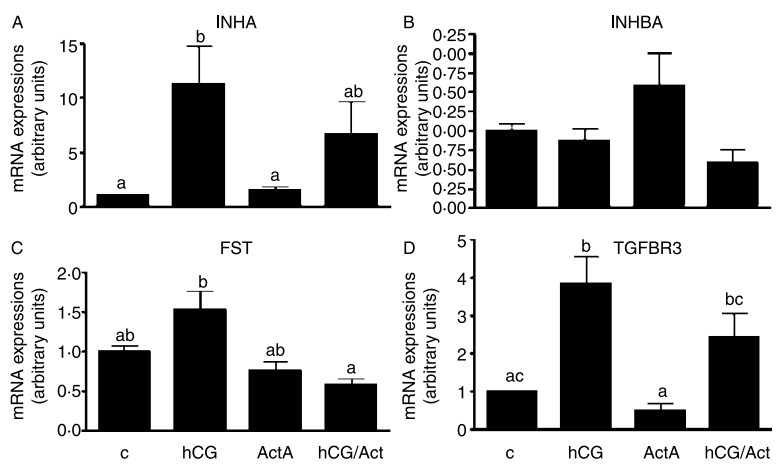

Figure 6 The likely effect of hCG and activin A on activin action. (A) In primary cultures of luteinised granulosa cells, hCG upregulated the expression of the inhibin $\alpha$ subunit (IHNA; $P<0 \cdot 01$, ANOVA) compared with controls (C), while activin A (Act) tended to attenuate this effect. (B) HCG alone had no effect upon the expression of the common $\beta$ A subunit (INHBA; $P>0 \cdot 05$, ANOVA), while activin $A$ tended to upregulate it. The activin A effect was diminished in cultures exposed to hCG and activin A concurrently (hCG/Act). (C) HCG tended to increase the expression of the activin inhibitor follistatin (FST), while activin A alone had no effect, it reduced the hCG effect in co-treatments $(P<0 \cdot 01$, ANOVA).

(D) The inhibin co-receptor $\beta$-glycan (TGFBR3) was significantly augmented with hCG $(P<0 \cdot 001$, ANOVA $)$ and although activin A had no effect on receptor expression, co-treatment with hCG tended to decrease the hCG response. These cells are the same cells as illustrated in Fig. 4. 
et al. 1978, Murphy 2000). The nature of these molecules is not entirely clear but it is likely that members of the TGF- $\beta$ family are involved (Shimasaki et al. 1999, Glister et al. 2005).

One member of the TGF- $\beta$ superfamily that does have a role in follicular granulosa cell function is activin A. Activin A is locally produced by follicles, predominantly smaller follicles, during their growth phase (Knight \& Glister 2006). As a follicle matures activin continues to be produced but the follicular microenvironment becomes less activin dominant and more inhibin/follistatin dominant (Hillier 1991, Yamoto et al. 1992, Roberts et al. 1993, Schneyer et al. 2000). However, it is well established that activins are imperative for follicular granulosa cell proliferation, FSH receptor regulation, FSH-induced aromatase expression, decreased theca cell androgen production, and increased oocyte maturation (Knight \& Glister 2006). While a trophic role in the follicle is apparent, the role for activin A in the corpus luteum is less clear. Indeed, in women, its concentrations tend to increase towards luteolysis (Muttukrishna et al. 1996) and its local actions appear to facilitate luteolysis (Myers et al. 2007a). As activin A appears to have a positive role in the follicle and a negative role in the corpus luteum, its activity appears to be suppressed at the follicular-luteal transition.

Activin action is tightly regulated at several different levels (Harrison et al. 2005). The expression of the $\alpha$ subunit itself is regulated (Hillier 1991, Roberts et al. 1993) and in the presence of $\beta$ A upregulation of the $\alpha$-subunit will push the synthesis of inhibin A rather than activin A. Inhibin A will also inhibit activin $A$ at the level of its receptor by binding to $\beta$-glycan to complex with the activin receptor and inhibit activin action (Lewis et al. 2000). In addition, follistatin secretion is also regulated. Follistatin binds irreversibly to activin to neutralise its bioactivity (Nakamura et al. 1990, Kogawa et al. 1991). We hypothesised that during ovulation one of the actions of $\mathrm{LH} / \mathrm{hCG}$ was to change the follicular environment to inhibit activin action and this would facilitate luteinisation. In the present study, we aimed to analyse the effect of hCG on the expression of luteinisation and activinassociated genes in primary cultures of luteinised granulosa cells and investigate whether maintaining activin A action was able to inhibit or interfere with the effects of hCG in these already luteinised cells. Primary cell scarcity meant that we were unable to investigate changes in protein expression at the same time as mRNA expression. However, we were able to confirm parallel protein changes at a tissue and functional level. In addition, previous studies have shown a strong correlation between mRNA concentrations in these cells and functional protein expression (Myers et al. 2007b).

One of the effects of hCG is to promote the expression of genes involved in the synthesis of progesterone. While follicular granulosa cells predominantly secrete oestradiol, the granulosalutein cells are also able to secrete up to 100-fold greater amounts of progesterone. Indeed, it has been estimated that the human corpus luteum can secrete up to $40 \mathrm{mg}$ of progesterone per day during the menstrual cycle. This is secondary to the increasing expression of $\mathrm{LH}$ receptors, STAR, P450 side chain cleavage and $3 \beta H S D$ during luteinisation. The expression of STAR and HSD3B1 in luteinised granulosa cells was increased by hCG, while activin A could inhibit the increase in response to hCG in a dose-dependent manner. In addition, hCG increased progesterone secretion and this could be attenuated by the addition of activin A. Activins are well known to have inhibitory effects upon basal and hCG-induced progesterone secretion in dispersed cultures of granulosa-lutein cells in both the macaque (Brannian et al. 1992) and in women (Di Simone et al. 1994).

However, activin A does not just interfere with hCG action as it has direct actions on luteinised granulosa cells. Activin decreased LHCGR expression directly and increased FSHR expression in a dose-dependent fashion using physiologically relevant concentrations. FSH and its seven-transmembrane receptor are essential for successful follicular development and granulosa cell function (Kumar et al. 1997, Dierich et al. 1998); however, once granulosa cells have differentiated into those of the corpus luteum, it appears to play a much less important role. Studies in rats have shown that $\mathrm{FSH}$ receptor expression is downregulated during luteinisation (Camp et al. 1991), while in vitro cell studies have shown that hCG treatment completely abolishes the receptor expression (Nakamura et al. 1991). As well as inhibiting hCG-induced progesterone synthesis, activin A directly induced a more follicular phenotype on already luteinised granulosa cells. These results highlight the importance of adequately suppressing active activin action during luteinisation and maintaining this suppression in the functional luteal phase, so that progesterone synthesis is not interrupted.

It is not just the progesterone synthesis pathway that changes during luteinisation. Another change is in the metabolism of cortisol by steroidogenic cells during the follicular and luteal phases. The $11 \beta \mathrm{HSD}$ enzymes control cortisol metabolism by their type 1 (that tends to generate cortisol) and type 2 (that tends to inactivate cortisol) isoforms. Numerous studies have shown clear evidence that there is a switch in $11 \beta \mathrm{HSD}$ isoforms associated with the follicularluteal transition (Michael et al. 1997, Tetsuka et al. 1997, Yong et al. 2000, Thurston et al. 2003). We have confirmed this switch in women at a protein level and localised expression to the granulosa/granulosa-lutein cells of the ovary. HSD11B1 protein is not found in antral follicular granulosa cells whilst HSD11B2 is abundant. Similar to the mRNA transcripts patterns observed in the human corpus luteum (Myers et al. $2007 b$ ), both $11 \beta$ HSD isoforms are present in granulosalutein cells; however, there has been a marked switch in the predominant isoform to type 1 with only low levels of type 2 still detectable. We have now shown that activin A suppresses hCG actions on HSD11B1 expression, while hCG attenuates activin actions on HSD11B2. These responses in luteinised granulosa cells give important insights into the switch in $11 \beta \mathrm{HSD}$ isoforms that consequently predict the local cortisol environment in the follicular or luteal phase and highlight the regulation of $11 \beta \mathrm{HSD}$ expression, and the opposing actions of hCG and activin, during luteinisation. 
The opposing action of hCG and activin A during luteinisation can also be seen when the expression of $\operatorname{ER} \alpha$ is investigated. Although the corpus luteum of women and primates express oestradiol receptors in the form of $\operatorname{ER} \beta$ (Duffy et al. 2000, Saunders et al. 2000), the steroidogenic cells of the primate corpus luteum, unlike follicular granulosa cells, are generally thought not to express ER $\alpha$ (Iwai et al. 1990, Chandrasekher et al. 1994). Here, we have immunolocalised ER $\alpha$ to the nuclei of granulosa cells of antral follicles and shown no immunolocalisation in the granulosa-lutein cells of the corpus luteum. We believe that the pre-ovulatory $\mathrm{LH}$ surge may be involved in switching off follicular ER $\alpha$ expression as the granulosa cells differentiate into granulosalutein cells of the corpus luteum. Our cell culture results suggest that ESR 1 is differentially regulated by activin A and hCG in luteinised granulosa cells as without activin A in the system, hCG downregulated ESR 1 expression. These findings are consistent with work involving the oestrogen receptor null mice that suggest that $\mathrm{ER} \alpha$, unlike $\operatorname{ER} \beta$, tends not to facilitate granulosa cell differentiation in the periovulatory period (Couse et al. 2005). The role of LH/hCG in luteinisation is clear and facilitated by the reduction in activin action.

It is important to inhibit activin action during luteinisation. We have shown that the effect of activin A alone or in inhibiting hCG action is dose dependent. The effect of hCG in luteinised granulosa cells is to continue to remove activin action and this occurs at three levels: the synthesis of inhibin A, the increase in its receptor and the synthesis of the activin-binding protein follistatin. In corpora lutea and luteal cells in vitro (Illingworth et al. 1996, Muttukrishna et al. 1997) and in cultured luteinised granulosa cells (Myers et al. 2007a), hCG increases inhibin A expression. We have shown that hCG upregulated the $\alpha$ subunit and that activin $A$ itself can inhibit this response. Similarly hCG increases $\beta$-glycan expression and this is attenuated in the presence of activin. Indeed, hCG upregulates follistatin (Myers et al. 2007a) and activin inhibits this effect. As activin $A$ itself seems to be involved in promoting activin action, it is likely that continued $\mathrm{LH} / \mathrm{hCG}$ effects during luteinisation, and in the corpus luteum, by inhibiting activin would further reduce activin action in a feedback loop. As LH action seems to be abrogated in the corpus luteum during luteolysis (McNeilly et al. 1980, Messinis 1997), the inhibition of activin action will be reduced and activin may feed forward to increase its action and facilitate a role in luteolysis (Myers et al. 2007a) that will be self-limiting as steroidogenic cells are removed from the ovary (Yuan \& Giudice 1997).

One of the features of luteinisation is terminal differentiation and the cessation of cell division. We have not investigated the effect of activin A on the potential of the luteinised granulosa cells to divide. However, by showing that activin A can induce a more follicular granulosa cell phenotype of these cells, we suggest than the differentiation state of these cells may be more plastic than expected. Markers of the cell cycle, such as cyclin D2, are upregulated by FSH and downregulated by LH in granulosa cells (Sicinski et al. 1996). Conversely, p27 kip-1 a CDK inhibitor protein that inhibits entry into the cell cycle and maintains differentiation (Robker \& Richards 1998) is known to be expressed in granulosa cells in response to $\mathrm{LH}$ and along with $\mathrm{p} 21^{\mathrm{cip} 1}$ is maintained at high levels in (mouse) corpora lutea (Deng et al. 1995, Robker \& Richards 1998). Furthermore, mice deficient in the $\mathrm{p} 27^{\mathrm{kip}-1}$ gene show that corpora lutea formed after luteinisation do not stop proliferating (Tong et al. 1998). We suspect that activin A may be able to facilitate cell division in luteinised cells just as it can in FSH-treated unluteinised granulosa cells (Li et al. 1995, Matzuk et al. 1996, Kumar et al. 1997, Ogawa et al. 2003). Indeed, a preliminary report suggested increased cell numbers in cultures of human luteinised granulosa cells grown in the presence of activin A (Rabinovici et al. 1990), although it should be noted that this study reports only an increase in cell number and it cannot be excluded that the increase in number may be attributed to other contaminating cell types (i.e. fibroblasts, endothelial cells; Duncan et al. 2005b) that are not terminally differentiated. It is clear from both in vivo and in vitro studies that activins do promote follicular granulosa cells proliferation, however, whether or not they can 'rescue' or 'revert' the luteinised granulosa phenotype remains unknown.

The identification of activins having a role in luteinisation is not novel. This research, however, focuses on the luteinised granulosa cell as a luteal cell that has already been luteinised by hCG. In that circumstance, activin A action appears to be inhibited. If activin A is put back in the system, it can inhibit hCG action and has a direct anti-luteinisation effect. It seems that removal of activin is important to form the corpus luteum. As increased activin $\mathrm{A}$ in the late luteal phase can facilitate removal of the corpus luteum, it appears that activin A is antiluteal at both extremes of the luteal lifespan (Myers et al. 2007a). The Smad4 conditional knockout mouse model is another system that provides evidence for activin $A$ as an inhibitor of luteinisation. These mice demonstrate a loss of both TGF- $\beta$ and activin signalling with targeted disruption of the common Smad 4 in ovarian granulosa cells (Pangas et al. 2006). Premature luteinisation of the follicular granulosa cells was one of the key phenotypes of this mouse, which was clearly evident by an upregulation of genes associated with luteinisation. Luteal markers such as the LH receptor, STAR, cholesterol side-chain cleavage and $3 \beta \mathrm{HSD}$ were all upregulated in the absence of activin signalling, while FSH receptor was slightly downregulated. Indeed, disrupted activin action in mature ovaries of the mouse resulted in an excess of corpora lutea (Pangas et al. 2007).

It should be remembered that luteinised granulosa cells as a model system have some deficiencies. These cells are already luteinised when they are collected, and longitudinal studies using non-luteinised granulosa cells would be ideal. Unfortunately, obtaining enough human granulosa cells to carry out such experiments is fraught with difficulty. In addition, these cells lack the three-dimensional regulatory and cellular environment seen in the developing corpus luteum and as such differ from mature granulosa-lutein cells. They do, however, share many important features such as chronic and acute regulated gene expression and hCG responsiveness and 
its magnitude (Duncan et al. 2005a,b, Myers et al. 2007a,b). They are also exposed to supraphysiological hormone concentrations, and maximal $\mathrm{LH}$ receptor stimulation, before collection and this is the reason that a 5-day culture is used to return these cells to normal hCG responsiveness. Despite these caveats, there is no better model than primary cultures of luteinised granulosa cells for studying gene expression at luteinisation in women.

In summary, we have presented evidence that activin A and hCG have opposing molecular effects upon genes involved in the follicular-luteal transition. The regulation of granulosa cells during luteinisation is complex and is likely to involve multiple interactions, and many molecules, that are not yet understood. Our results, however, suggest that removal, or at least suppression of activin, from the system is very important for successful luteal function. In addition, the addition of activin to granulosa cells may help to maintain their follicular phenotype. We suggest that local activin action is detrimental to luteal function and structure, and that successful luteal function requires inhibition of activin action and luteal involution is facilitated by an increase in activin activity during luteolysis (Myers et al. 2007a).

\section{Declaration of interest}

The authors declare that there is no conflict of interest that could be perceived as prejudicing the impartiality of the research reported.

\section{Funding}

Michelle Myers is supported by an Overseas Research Student (ORS) Award Scheme, and the research was supported by the Cunningham Trust (W C D, S vdD).

\section{Author contribution statement}

W C D devised the concepts and interpretations in collaboration with A S $\mathrm{McN}$ and supervised the data collection, analysis and writing of the manuscript. $\mathrm{S} v \mathrm{dD}$ and $\mathrm{MM}$ designed and carried out the experiments and analysed the data. MM prepared the figures and wrote the manuscript.

\section{Acknowledgements}

The authors would like to thank Dr K J Thong and the patients, clinical fellows, embryologists and nursing staff of the Edinburgh Assisted Conception Unit for help in sample collection. We would also like to thank Nancy Evans for performing the in-house progesterone assay.

\section{References}

Brankin V, Mitchell MR, Webb B \& Hunter MG 2003 Paracrine effects of oocyte secreted factors and stem cell factor on porcine granulosa and theca cells in vitro. Reproductive Biology and Endocrinology 155.

Brannian JD, Woodruff TK, Mather JP \& Stouffer RL 1992 Activin-A inhibits progesterone production by macaque luteal cells in culture. Journal of Clinical Endocrinology and Metabolism 75 756-761.
Camp TA, Rahal JO \& Mayo KE 1991 Cellular localization and hormonal regulation of follicle-stimulating hormone and luteinizing hormone receptor messenger RNAs in the rat ovary. Molecular Endocrinology 5 1405-1417.

Casagrandi D, Bearfield C, Geary J, Redman CW \& Muttukrishna S 2003 Inhibin, activin, follistatin, activin receptors and $\beta$-glycan gene expression in the placental tissue of patients with pre-eclampsia. Molecular Human Reproduction 9 199-203.

Chandrasekher YA, Melner MH, Nagalla SR \& Stouffer RL 1994 Progesterone receptor, but not estradiol receptor, messenger ribonucleic acid is expressed in luteinizing granulosa cells and the corpus luteum in rhesus monkeys. Endocrinology 135 307-314.

Channing CP, Hillensjo T \& Schaerf FW 1978 Hormonal control of oocyte meiosis, ovulation and luteinization in mammals. Journal of Clinical Endocrinology and Metabolism 7 601-624.

Channing CP, Schaerf FW, Anderson LD \& Tsafriri A 1980 Ovarian follicular and luteal physiology. International Review of Physiology 22 117-201.

Coskun S, Uzumcu M, Lin YC, Friedman CI \& Alak BM 1995 Regulation of cumulus cell steroidogenesis by the porcine oocyte and preliminary characterization of oocyte-produced factor(s). Biology of Reproduction $\mathbf{5 3}$ 670-675.

Couse JF, Yates MM, Deroo BJ \& Korach KS 2005 Estrogen receptor- $\beta$ is critical to granulosa cell differentiation and the ovulatory response to gonadotropins. Endocrinology 146 3247-3262.

Deng C, Zhang P, Harper JW, Elledge SJ \& Leder P 1995 Mice lacking p21CIP1/WAF1 undergo normal development, but are defective in G1 checkpoint control. Cell 82 675-684.

Dierich A, Sairam MR, Monaco L, Fimia GM, Gansmuller A, LeMeur M \& Sassone-Corsi P 1998 Impairing follicle-stimulating hormone (FSH) signaling in vivo: targeted disruption of the FSH receptor leads to aberrant gametogenesis and hormonal imbalance. PNAS 95 13612-13617.

van den Driesche S, Smith VM, Myers M \& Duncan WC 2008 Expression and regulation of oestrogen receptors in the human corpus luteum. Reproduction 135 509-517.

Duffy DM, Chaffin CL \& Stouffer RL 2000 Expression of estrogen receptor alpha and beta in the rhesus monkey corpus luteum during the menstrual cycle: regulation by luteinizing hormone and progesterone. Endocrinology 141 1711-1717.

Duncan WC, Gay E \& Maybin JA 2005a The effect of human chorionic gonadotrophin on the expression of progesterone receptors in human luteal cells in vivo and in vitro. Reproduction 130 83-93.

Duncan WC, Hillier SG, Gay E, Bell J \& Fraser HM 2005b Connective tissue growth factor (CTGF) expression in the human corpus luteum: paracrine regulation by human chorionic gonadotropin (hCG). Journal of Clinical Endocrinology and Metabolism 90 5366-5376.

Eppig JJ, Wigglesworth K, Pendola F \& Hirao Y 1997 Murine oocytes suppress expression of luteinizing hormone receptor messenger ribonucleic acid by granulosa cells. Biology of Reproduction 56 976-984.

Filicori M 1999 The role of luteinizing hormone in folliculogenesis and ovulation induction. Fertility and Sterility 71 405-414.

Fraser HM \& Duncan WC 2005 Vascular morphogenesis in the primate ovary. Angiogenesis 8 101-116.

Glister C, Richards SL \& Knight PG 2005 Bone morphogenetic proteins (BMP) $-4,-6$, and -7 potently suppress basal and luteinizing hormoneinduced androgen production by bovine theca interna cells in primary culture: could ovarian hyperandrogenic dysfunction be caused by a defect in thecal BMP signaling? Endocrinology 146 1883-1892.

Harrison CA, Gray PC, Vale WW \& Robertson DM 2005 Antagonists of activin signaling: mechanisms and potential biological applications. Trends in Endocrinology and Metabolism 16 73-78.

Henderson TA, Saunders PT, Moffett-King A, Groome NP \& Critchley HO 2003 Steroid receptor expression in uterine natural killer cells. Journal of Clinical Endocrinology and Metabolism 88 440-449.

Hillier SG 1991 Regulatory functions for inhibin and activin in human ovaries. Journal of Endocrinology 131 171-175.

Hutchinson LA, Findlay JK, de Vos FL \& Robertson DM 1987 Effects of bovine inhibin, transforming growth factor-beta and bovine Activin-A on granulosa cell differentiation. Biochemical and Biophysical Research Communications 146 1405-1412. 
Illingworth PJ, Groome NP, Duncan WC, Grant V, Tovanabutra S, Baird DT \& McNeilly AS 1996 Measurement of circulating inhibin forms during the establishment of pregnancy. Journal of Clinical Endocrinology and Metabolism 81 1471-1475.

Iwai T, Nanbu Y, Iwai M, Taii S, Fujii S \& Mori T 1990 Immunohistochemical localization of oestrogen receptors and progesterone receptors in the human ovary throughout the menstrual cycle. Virchows Archiv. A, Pathological Anatomy and Histopathology 417 369-375.

Ji Q, Chen P, Aoyoma C \& Liu P 2002 Increased expression of human luteinizing hormone/human chorionic gonadotropin receptor mRNA in human endometrial cancer. Molecular and Cellular Probes 16 269-275.

Knight PG \& Glister C 2006 TGF-beta superfamily members and ovarian follicle development. Reproduction 132 191-206.

Kogawa K, Nakamura T, Sugino K, Takio K, Titani K \& Sugino H 1991 Activinbinding protein is present in pituitary. Endocrinology 128 1434-1440.

Kumar TR, Wang Y, Lu N \& Matzuk MM 1997 Follicle stimulating hormone is required for ovarian follicle maturation but not male fertility. Nature Genetics 15 201-204.

Ledwitz-Rigby F, Rigby BW, Gay VL, Stetson M, Young J \& Channing CP 1977 Inhibitory action of porcine follicular fluid upon granulosa cell luteinization in vitro: assay and influence of follicular maturation. Journal of Endocrinology 74 175-184.

Lewis KA, Gray PC, Blount AL, MacConell LA, Wiater E, Bilezikjian LM \& Vale W 2000 Betaglycan binds inhibin and can mediate functional antagonism of activin signalling. Nature 404 411-414.

Li R, Phillips DM \& Mather JP 1995 Activin promotes ovarian follicle development in vitro. Endocrinology 136 849-856.

Matzuk MM, Kumar TR, Shou W, Coerver KA, Lau AL, Behringer RR \& Finegold MJ 1996 Transgenic models to study the roles of inhibins and activins in reproduction, oncogenesis, and development. Recent Progress in Hormone Research 51 123-157.

McNeilly AS, Kerin J, Swanston IA, Bramley TA \& Baird DT 1980 Changes in the binding of human chorionic gonadotrophin/luteinizing hormone, follicle-stimulating hormone and prolactin to human corpora lutea during the menstrual cycle and pregnancy. Journal of Endocrinology 87 315-325.

Messinis IE 1997 Luteal function - luteolysis. Annals of the New York Academy of Sciences 816 151-157.

Michael AE, Evagelatou M, Norgate DP, Clarke RJ, Antoniw JW, Stedman BA, Brennan A, Welsby R, Bujalska I, Stewart PM et al. 1997 Isoforms of 11ß-hydroxysteroid dehydrogenase in human granulosa-lutein cells. Molecular and Cellular Endocrinology 132 43-52.

Murphy BD 2000 Models of luteinization. Biology of Reproduction 63 2-11. Muttukrishna S, Fowler PA, George L, Groome NP \& Knight PG 1996 Changes in peripheral serum levels of total activin A during the human menstrual cycle and pregnancy. Journal of Clinical Endocrinology and Metabolism 81 3328-3334.

Muttukrishna S, Groome N \& Ledger W 1997 Gonadotropic control of secretion of dimeric inhibins and activin A by human granulosa-luteal cells in vitro. Journal of Assisted Reproduction and Genetics 14 566-574.

Myers M, Gay E, McNeilly AS, Fraser HM \& Duncan WC 2007a In vitro evidence suggests activin-A may promote tissue remodeling associated with human luteolysis. Endocrinology 148 3730-3739.

Myers M, Lamont MC, van den Driesche S, Mary N, Thong KJ, Hillier SG \& Duncan WC 2007b The role of luteal glucocorticoid metabolism during maternal recognition of pregnancy in women. Endocrinology 148 5769-5779.

Nakamura T, Takio K, Eto Y, Shibai H, Titani K \& Sugino H 1990 Activinbinding protein from rat ovary is follistatin. Science 247 836-838.

Nakamura K, Minegishi T, Takakura Y, Miyamoto K, Hasegawa Y, Ibuki Y \& Igarashi M 1991 Hormonal regulation of gonadotropin receptor mRNA in rat ovary during follicular growth and luteinization. Molecular and Cellular Endocrinology 82 259-263.

Ogawa T, Yogo K, Ishida N \& Takeya T 2003 Synergistic effects of activin and FSH on hyperphosphorylation of $\mathrm{Rb}$ and $\mathrm{G} 1 / \mathrm{S}$ transition in rat primary granulosa cells. Molecular and Cellular Endocrinology 210 31-38.

Oskarsson A, Ulleras E, Plant KE, Hinson JP \& Goldfarb PS 2006 Steroidogenic gene expression in H295R cells and the human adrenal gland: adrenotoxic effects of lindane in vitro. Journal of Applied Toxicology 26 484-492.
Pangas SA, Li X, Robertson EJ \& Matzuk MM 2006 Premature luteinization and cumulus cell defects in ovarian-specific Smad4 knockout mice. Molecular Endocrinology 20 1406-1422.

Pangas SA, Jorgez CJ, Tran M, Agno J, Li X, Brown CW, Kumar TR \& Matzuk MM 2007 Intraovarian activins are required for female fertility. Molecular Endocrinology 21 248-257.

Rabinovici J, Spencer SJ \& Jaffe RB 1990 Recombinant human activin-A promotes proliferation of human luteinized preovulatory granulosa cells in vitro. Journal of Clinical Endocrinology and Metabolism 71 1396-1398.

Rae MT, Niven D, Critchley HO, Harlow CR \& Hillier SG 2004 Antiinflammatory steroid action in human ovarian surface epithelial cells. Journal of Clinical Endocrinology and Metabolism 89 4538-4544.

Roberts VJ, Barth S, el-Roeiy A \& Yen SS 1993 Expression of inhibin/activin subunits and follistatin messenger ribonucleic acids and proteins in ovarian follicles and the corpus luteum during the human menstrual cycle. Journal of Clinical Endocrinology and Metabolism 77 1402-1410.

Robker RL \& Richards JS 1998 Hormone-induced proliferation and differentiation of granulosa cells: a coordinated balance of the cell cycle regulators cyclin D2 and p27Kip1. Molecular Endocrinology 12 924-940.

Salas C, Julio-Pieper M, Valladares M, Pommer R, Vega M, Mastronardi C, Kerr B, Ojeda SR, Lara HE \& Romero C 2006 Nerve growth factordependent activation of trkA receptors in the human ovary results in synthesis of follicle-stimulating hormone receptors and estrogen secretion. Journal of Clinical Endocrinology and Metabolism 91 2396-2403.

Saunders PT, Millar MR, Williams K, Macpherson S, Harkiss D, Anderson RA, Orr B, Groome NP, Scobie G \& Fraser HM 2000 Differential expression of estrogen receptor- $\alpha$ and $-\beta$ and androgen receptor in the ovaries of marmosets and humans. Biology of Reproduction 63 1098-1105.

Schneyer AL, Fujiwara T, Fox J, Welt CK, Adams J, Messerlian GM \& Taylor AE 2000 Dynamic changes in the intrafollicular inhibin/activin/follistatin axis during human follicular development: relationship to circulating hormone concentrations. Journal of Clinical Endocrinology and Metabolism $\mathbf{8 5}$ 3319-3330.

Seifer DB, Freeman MR, Gardiner AC, Hill GA, Schneyer AL \& Vanderhyden BC 1996 Autologous granulosa cell coculture demonstrates zygote suppression of granulosa cell steroidogenesis. Fertility and Sterility $\mathbf{6 6}$ 425-429.

Shidaifat F 2001 Effect of activin-A on goat granulosa cell steroidogenesis. Theriogenology 56 591-599.

Shidaifat F, Khamas W \& Hailat N 2001 Activin-A differentially regulates steroidogenesis by sheep granulosa cells. Research in Veterinary Science 71 23-25.

Shimasaki S, Zachow RJ, Li D, Kim H, Iemura S, Ueno N, Sampath K, Chang RJ \& Erickson GF 1999 A functional bone morphogenetic protein system in the ovary. PNAS $967282-7287$.

Shukovski L, Findlay JK \& Robertson DM 1991 The effect of folliclestimulating hormone-suppressing protein or follistatin on luteinizing bovine granulosa cells in vitro and its antagonistic effect on the action of activin. Endocrinology 129 3395-3402.

Shukovski L, Dyson M \& Findlay JK 1993 The effects of follistatin, activin and inhibin on steroidogenesis by bovine thecal cells. Molecular and Cellular Endocrinology 97 19-27.

Sicinski P, Donaher JL, Geng Y, Parker SB, Gardner H, Park MY, Robker RL, Richards JS, McGinnis LK, Biggers JD et al. 1996 Cyclin D2 is an FSHresponsive gene involved in gonadal cell proliferation and oncogenesis. Nature 384 470-474.

Di Simone N, Lanzone A, Petraglia F, Ronsisvalle E, Caruso A \& Mancuso S 1994 Effect of activin-A on progesterone synthesis in human luteal cells. Fertility and Sterility 62 1157-1161.

Stocco C, Telleria C \& Gibori G 2007 The molecular control of corpus luteum formation, function, and regression. Endocrine Reviews 28 117-149.

Tetsuka M, Thomas FJ, Thomas MJ, Anderson RA, Mason JI \& Hillier SG 1997 Differential expression of messenger ribonucleic acids encoding $11 \beta$-hydroxysteroid dehydrogenase types 1 and 2 in human granulosa cells. Journal of Clinical Endocrinology and Metabolism 82 2006-2009.

Thurston LM, Chin E, Jonas KC, Bujalska IJ, Stewart PM, Abayasekara DR \& Michael AE 2003 Expression of $11 \beta$-hydroxysteroid dehydrogenase $(11 \beta \mathrm{HSD})$ proteins in luteinizing human granulosa-lutein cells. Journal of Endocrinology 178 127-135. 
Tong W, Kiyokawa H, Soos TJ, Park MS, Soares VC, Manova K, Pollard JW \& Koff A 1998 The absence of p27Kip1, an inhibitor of G1 cyclindependent kinases, uncouples differentiation and growth arrest during the granulosa-luteal transition. Cell Growth and Differentiation 9 787-794.

Vanderhyden BC \& Macdonald EA 1998 Mouse oocytes regulate granulosa cell steroidogenesis throughout follicular development. Biology of Reproduction 59 1296-1301.

Vanderhyden BC, Cohen JN \& Morley P 1993 Mouse oocytes regulate granulosa cell steroidogenesis. Endocrinology 133 423-426.

Wehrenberg U \& Rune GM 2000 Spontaneous luteinization of antral marmoset follicles in vitro. Molecular Human Reproduction 6 504-509.

Yamoto M, Minami S, Nakano R \& Kobayashi M 1992 Immunohistochemical localization of inhibin/activin subunits in human ovarian follicles during the menstrual cycle. Journal of Clinical Endocrinology and Metabolism 74 989-993.
Yong PY, Thong KJ, Andrew R, Walker BR \& Hillier SG 2000 Development-related increase in cortisol biosynthesis by human granulosa cells. Journal of Clinical Endocrinology and Metabolism 85 4728-4733.

Yuan W \& Giudice LC 1997 Programmed cell death in human ovary is a function of follicle and corpus luteum status. Journal of Clinical Endocrinology and Metabolism 82 3148-3155.

Received in final form 28 July 2008

Accepted 7 August 2008

Made available online as an Accepted Preprint 18 August 2008 